\title{
A William Tecumseh Sherman Letter
}

\author{
RON A L D L. F I N G E R S O N
}

Pointing to four Civil War letters, General Henry Van Ness Boynton, Washington correspondent for the Cincinnati Commercial Gazette, reopened for public examination in the Sunday, January 23, 1887, New York Sun, the long-running subject of General Ulysses S. Grant's liquor drinking. The letters recalled a "foolish, drunken, stupid Grant," "drunk at Donelson," a Grant who had "pledged himself to drink nothing intoxicating," still "getting liquor in a surreptitious manner."1 Instant reactions of indignation, abuse, protest, and some agreement sprang forth from the Sun's readers and from Grant's friends and relatives. The Reverend Doctor Funk remembered the battles that had been lost and the thousands of men slain needlessly because of drunkenness in high places. ${ }^{2}$ Major William C. Carroll wrote that there were only three men remaining, besides himself, who were qualified to speak knowledgeably on the subject of Grant's intemperance: General John E. Smith, Forty-fifth Illinois, Surgeon J. B. Kitto, Forty-fifth Illinois, and Colonel A. H. Markham, Army of the Tennessee. ${ }^{3}$ Grant's son, Colonel Frederick Dent Grant, spoke out against those assassins of others' reputations who "have for years been trying to ruin the fair fame of the purest man and the best father that ever lived."4 Dr. E. D.

${ }^{1}$ New York Sun, January 23, 1887, pp. 1-2. Letter from Murat Halstead to Salmon P. Chase, Cincinnati, Ohio, February 19, 1863. Letter from John A. Rawlins to Ulysses S. Grant, Vicksburg, Mississippi, June 8, 1863. Letter from John A. Rawlins to William F. Smith, City Point, Virginia, June 30, 1864. Letter from William F. Smith to Solomon Foot, College Point, Long Island, July 30, 1864.

2 New York Sun, January 26, 1887, p. 1. Reverend Funk spoke before The First Temperance Regiment.

3 Baltimore American, February 7, 1887, p. 2. Major William C. Carroll, Thirteenth Illinois Cavalry, served as Acting Aide-de-Camp to General John A. Logan, and Volunteer Aide to General Grant at Shiloh.

${ }^{4}$ New York Times, February 12, 1887, p. 5. Letter from Colonel Frederick D. Grant to Major William C. Carroll, New York, February 8, 1887, thanking Major Carroll for defending his father's good name. 
Kittoe confirmed the factual validity of General Boynton's statements. ${ }^{5}$ The University of Iowa Library's recently-acquired William Tecumseh Sherman letter adds still another voice to the controversy:

Army Building,

New York, Feb 4, 1887

Dear Tourtelotte, ${ }^{6}$

Yours of Feb 1. is received and as it asks some questions I answer at once-I have not heard of or encountered either of the two girls of Morgan L. Smith, both of whom must now be grown-Some years ago I was told the elder girl had developed quite a character as Authoress or Poet, and that she was earning a good living by writing for the magazines. I think the mother had got low down before she died. She borrowed of me, [ ] Miller \& Corkhill pretty heavy in Washington-always on the assertion that she had some Claim against the PO Dept on the eve of Settlement.-Of course I never expected to be repaid.-That was a small matter for Bragg, to strike off the Army Bill the item for my Clerk-John Sherman says Mr Allison of the Com on Appropriations promises it will appear on the Sunday Civil Bill-but I am getting tired of being a beggar for such a small favor - [ ] Mr. Lin Hodges has paid Mr. [ ] for January, the first cent he has received from Uncle Sam since he left St Louis-I advanced him $\$ 400$. and enabled him to earn $\$ 100$. by selling to the Tribune Copies of two letters at the time of Logans death-Now if the 4th of March passes without the appropriation, I will discharge my Clerk box up \& store my papers and simply refuse to answer soldiers' letters.

The Newspaper Clipping you sent I had seen here in the Sun-It fell still-born. Boynton is a Coyote, or hyena, scratching up old forgotten scandals, publishing them as something new-We all knew at the time that Genl Grant would occasionally drink too much. He always encouraged me to talk to him frankly of this \& other things and I always noticed that he could with an hours sleep wake up perfectly sober \& bright-and when any thing was pending he was invariably abstinent of drink-After Vicksburg, you must remember that a delegation of preachers waited on President Lincoln to complain of Grants habit-Mr Lincoln heard them patiently and enquired-"Do you know where Grant buys his whiskey? I would like to present some to other Generals not so successful."

Mr Lincoln knew all that Boynton now reveals \& more-but Mr Lincoln wanted success, and had more sense than a thousand Boyntons-Halsteds \&c who from their safe places in the rear knew how to fight battles, and to hold the Generals responsible, for high water crowded camps and the con-

5 New York Daily Tribune, January 28, 1887, p. 3. Dr. E. D. Kittoe, a member of General Grant's staff, said "that General Boynton's statements were founded on facts which are well known to every survivor of Grant's military family . . . and to many others who held intimate personal relations with him."

${ }^{6}$ Colonel John E. Tourtellotte was General William Tecumseh Sherman's aidede-camp from January 1,1871 to February 8, 1884. 
sequent pestilence which we tried to hide from the Country, and even from the men-I well remember when the high water of the Mississippi drove us to the Levees which were also the only burial places, when the living \& dead lay with but a foot of damp earth between, when Grant \& his army demonstrated the largest measure of patience and Courage and perseverance, whilst Halsted in Cincinati by just such articles as the one here displayed was trying to create panic, mistrust and failure. It is not my office to defend General Grant, for time has stamped his fame as real-not accidental or meretricious, and I only refer to this publication of Boynton because you sent it to me, and may think it is something new-No it is as old as that most wonderful Series of Events which began with the Mexican War, 1846.

Grants whole character was a mystery even to himself-a combination of Strength and weakness not paralleled by any of whom I have read in ancient or Modern History-The good he did lives after him-let his small weaknesses lie buried with his bones-and Shame on the Curs and Coyotes who aim to rake them up again.

Mr. Thackara came over from Philadelphia yesterday and took Elly home to Bryn Mawr-Lizzie will come back Monday-

Rachel is off today with the wife of Hamilton Fish Sr to wish [ for a Toboganning match.-I am advertised for an Exhibition of Capt Pratts Carlisle Indian School at the Academy of Music, tonight-and tomorrow Dinner with Chauncey M. Depew-Our expenses are gradually drawing ahead of my income, and I must begin to economise-The item Carriage [ ] begins to run into the hundreds per month-

We all retain our usual health-Genl Stone left 3 Policies of Insurance each $\$ 10,000$ but I dont know as to their condition-His family of 3 children are all delicate $\&$ must go to Louisiana, the native place of Mrs Stone-

as always Yr Friend,

Wm. T. Sherman

General Sherman's allegation that Murat Halstead, editor of the Cincinnati Commercial Gazette, was guilty of criticizing Civil War actions from a safe place in the rear may have had some validity, but the same could hardly be said of Medal of Honor recipient Henry Van Ness Boynton. One has only to refer to the several detailed accounts remaining witness to Lieutenant-Colonel Boynton's heroism at Chattanooga and Missionary Ridge, Tennessee ${ }^{7}$ and his immediate ac-

${ }^{7}$ E.g., Report of Major Joseph L. Budd, Thirty-fifth Ohio Volunteer Infantry, Chattanooga, Tennessee, November $30,1863, "$. . . The regiment, led by Lieutenant-Colonel Boynton, started at a double-quick, cheering with hearty good will, and pressed on utterly regardless of the fire of musketry ... I was informed that Lieutenant-Colonel Boynton had received a severe wound in the thigh." (U.S. War Department, The War of the Rebellion: A Compilation of the Official Records of the Union and Confederate Armies, [Washington: Government Printing Office, 
tion taken to meet Sherman's army at Savannah on his first newspaper assignment after release from the service ${ }^{8}$ to disprove any such similar allegations made of Boynton. It was not Boynton's writing from lack of military experience that won him enemies in high places but rather his determined, ever-present insistence on correct, accurate historiography devoid of romantic frills. General William Tecumseh Sherman had personal reasons for resenting Henry Van Ness Boynton's probes into official records and his criticisms of writing history from memory alone. Sherman doubtless smarted a good deal from Boynton's attack on his Memoirs. ${ }^{9}$

Five days after General Boynton's article, "Grant's Liquor Drinking," first appeared in the New York Sun, the Sun's editor ran another article entitled "Gen. Grant's Occasional Intoxication." General Sherman's letter to Colonel Tourtellotte echoes the appeal made in this Friday, January 28, 1887 article. ${ }^{10}$ President Lincoln, Secretary of War Stanton, and the American people collectively could not be wrong. Occasional drunkenness in a General of the Army and President of the United States did not constitute a denial of responsibility, and Boynton was wrong to make such an implication publicly.

Biographers and historians have acknowledged Grant's liquor drinking. General Sherman in his letter to Colonel Tourtellotte conceded "that General Grant would occasionally drink too much." The remaining question raised in Sherman's letter is not whether or not Grant

1890]), ser. I, vol. XXXI, pt. II, p. 538. Boynton received the medal of honor for his action at Missionary Ridge, Tennessee, November 25, 1863.

${ }^{8}$ New York Daily Tribune, October 23, 1875, p. 4.

9 Henry Van Ness Boynton wrote in the Preface of his book entitled Sherman's Historical Raid (Cincinnati: Wilstach, Baldwin, and Company, 1875), p. 3, "The object of the present compilation .... is to show wherein the Memoirs of General Sherman fall far short of presenting the correct history of many great events of which they treat; how much they lack of giving a complete account of incidents which they relate; how far the author's recollection, even when corrected by his own memoranda, is at fault; and to furnish the future historian with facts which will guard him against perpetuating the error and the injustice which pervade both volumes of the work."

${ }^{10}$ New York Sun, January 28, 1887, p. 2. “. . . the truth remains unaffected that Mr. Lincoln and Mr. Stanton were in the right when, knowing the facts, they not only continued Grant in his command, but promoted him . . . the head of all the military forces of the country ... We conclude now, as Mr. Lincoln and Mr. Stanton concluded ... that while this tendency to occasional drunkenness constituted a serious defect in Grant's character, it really did not disqualify him for successful command ... The same view ... . was also taken by the American people when they twice chose Grant President ..." See also William H. Townsend, Lincoln and Liquor (New York: Press of the Pioneers, Inc., 1934), p. 132 and Charles T. White, Lincoln and Prohibition (New York: Abingdon Press, 1921), p. 93. 
drank too much, but whether or not Boynton deserved the labels coyote, hyena, and cur for publicly reopening the subject of Grant's drinking. The records will show that he did not. Henry Boynton took his role as a journalist seriously. ${ }^{11}$ If he won enemies from airing too publicly the findings of his researches, he also won respect and admiration. ${ }^{12}$ General Boynton should be remembered for his courage in setting forth his views, not for the gods he made men.

${ }^{11}$ New York Sun, January 23, 1887, p. 1. General Boynton writes, "It is a question as to how far journalism can properly go in exposing the private vices of public men. There can be no doubt as to the propriety of its dealing fully and fearlessly with those vices, when through their effect the public interests are put in peril."

12 New York Daily Tribune, June 18, 1898, p. 3. "His work at the capitol did much to raise the tone of journalism there. He was intimate with all the prominent men, and trusted by them." New York Daily Tribune, October 9, 1875, p. 6. "No assailant [against Sherman's Memoirs] who has yet taken the field comes with anything like the combined military equipment and professional training which General H. V. Boynton brings to the task he has undertaken." New York Times, December 28, 1875, p. 5. Even General Kilpatrick bespoke the "comprehensive and able criticism by H. V. Boynton, Esq., whose practical pen has contributed so much that is interesting and useful to the war literature of the country." 


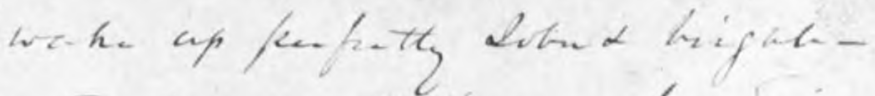

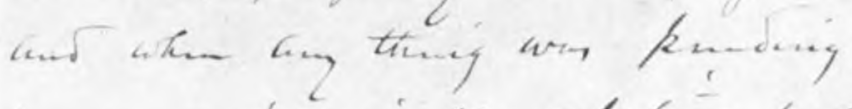

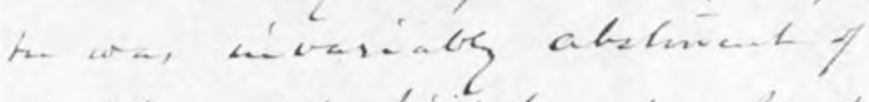

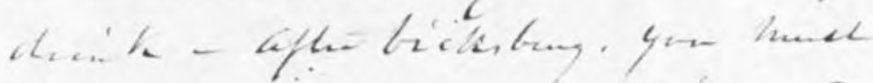

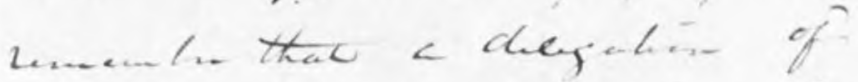

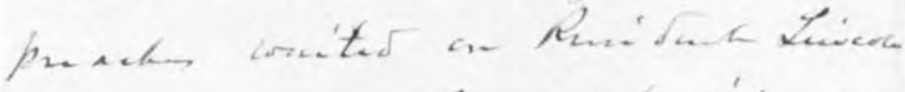

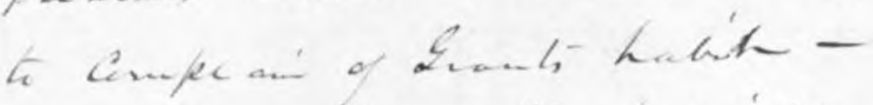

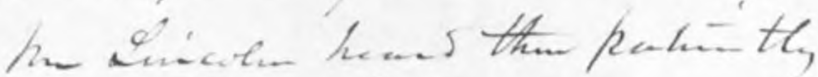

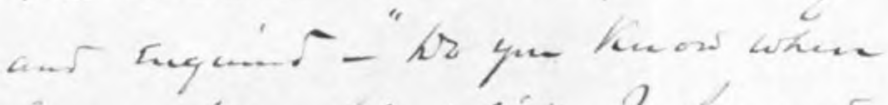

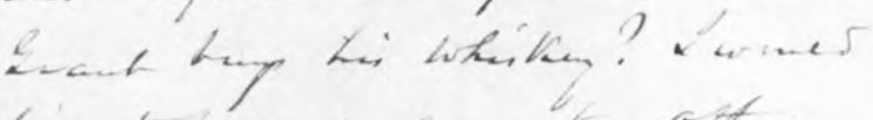

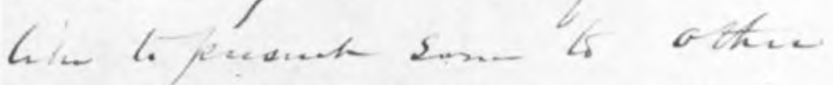

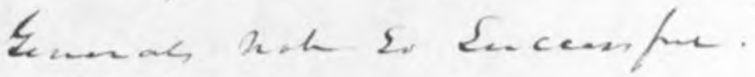

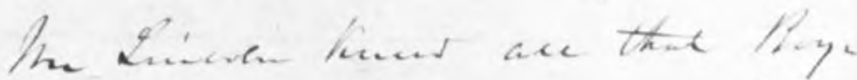

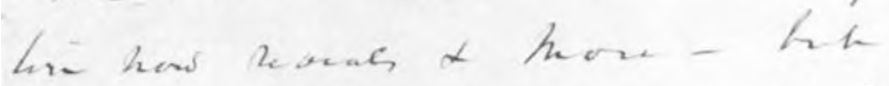

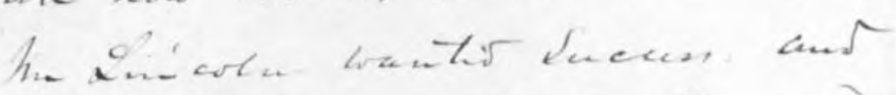

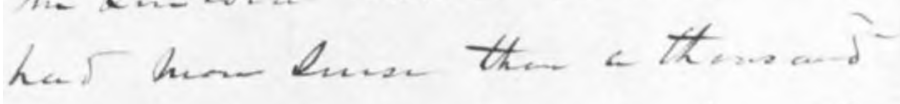

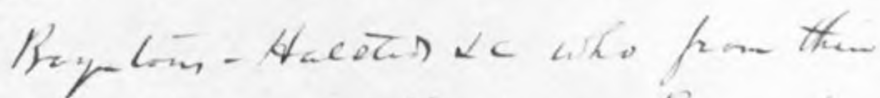

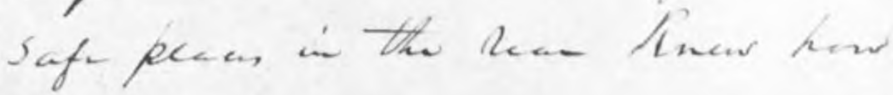

Portion of an antograph letter from William Tecumseh Sherman to Col. John E. Tourtellote, February t, 1887. 